\title{
Sosialisasi Internet Sehat, Cerdas, Kreatif dan Produktif di Era Pandemi COVID 19 pada MA NW Tanak Maik Masbagek
}

\author{
Muhammad Innuddin', Dedy Febry Rachman², Hairani ${ }^{3}$, Andi Sofyan Anas ${ }^{4}$, Hasbullah ${ }^{5}$ \\ inn@universitasbumigora.ac.id ${ }^{1}$, dedyfebry@universitasbumigora.ac.id ${ }^{2}$, \\ hairani@universitasbumigora.ac.id ${ }^{3}$, andi.sofyan@universitasbumigora.ac.id ${ }^{4}$, \\ hasbullah@universitasbumigora.ac.id ${ }^{5}$ \\ 1,2,3,4,5 UniversitasBumigora
}

\section{Article History:}

Received: 13-12-2021

Revised: 05-01-2022

Accepted: 10-01-2022
Keywords: Teachers, students, pandemic, ICT, internet and evaluation.

\begin{abstract}
Healthy, Smart, Creative and Productive Internet in the era of the Covid 19 Pandemic. The research objectives include: to find out how to use the technology and describing how to use technology properly to reduce negative impacts. This research method is a descriptive qualitative method. The techniques used in collecting data are observation techniques, interview techniques, and documentation. The results of this study found two problems, including 1) did not understand how to use and utilize internet technology properly, 2) lack of teacher evaluation and control on students. The conclusion of this research is the use and utilization of technology properly, leading to positive impacts and reducing negative impacts. By knowing how to use internet technology properly and correctly, it will be able to make students smart, creative, and productive. The purpose of being intelligent, creative, and productive is that students can develop and apply what has been obtained in internet technology, which is applied in their daily lives, both within the school environment or outside the school environment.
\end{abstract}

\section{Pendahuluan}

Internet merupakan perkembangan teknologi yang sangat pesat, tidak bias dipungkiri perkembangan teknologi menjadi kebutuhan pokok bagi setiap seseorang seluruh dunia. Internet merupakan kumpulan jaringan-jaringan computer sedunia yang saling berhubungan satu sama lain (Maryono \& Istiana, 2019). Sedangkan menurut Simargolang et al. (2021) internet adalah sebuah sistem yang menghubungkan dua device atau lebih menggunakan media komunikasi berupa kabel atau tanpa kabel (wireless).

Berdasarkan definisi teknologi internet menurut ahli di atas, dapat disimpulkan bahwa dengan adanya teknologi internet yang semakin berkembang dan pesat diseluruh dunia yang dapat digunakan dan dimanfaatkan dengan baik. Adapun teknologi internet akan berdampak buruk jika digunakan untuk hal yang tidak baik, akan tetapi teknologi internet akan berdampak sangat baik, apabila digunakan dan dimanfaatkan dengan baik, baik bagi anak-anak, remaja, dan orang dewasa. Pemanfaatan teknologi internet yang baik akan membuat hidup menjadi lebih baik juga, baik pemanfaatan internet sehat, baik kecerdasan, 
kreatif, dan produktif, khususnya di masa pandemic Covid 19.

Adapun dampak negatif dari penggunaan internet "Menurut survei global yang diadakan oleh Latitude News pada tahun 2012, Indonesia merupakan negara dengan kasus bullying tertinggi kedua di dunia setelah Jepang. Kasus bullying di Indonesia ternyata mengalahkan kasus bullying di Amerika Serikat yang menempati posisi ketiga. Ironisnya, kasus bullying di Indonesia lebih banyak dilakukan di media sosial. Badan Pusat Statistik mencatat pada tahun 2006 angka Cyberbullying yang terjadi di Indonesia mencapai angka 25 juta kasus di mulai dari kasus dengan skala ringan sampai dengan skala berat. Berdasarkan penelitian dari 210 responden, 91\% responden asal Indonesia mengaku telah melihat kasus cyberbullying" (Hakim et al., 2016).

"Menurut data Asosiasi Penyelenggara Jasa Internet Indonesia (APJII) menyatakan bahwa pertumbuhan pengguna internet di Indonesia meningkat 34,9\% pada tahun 2015 (Maulana, 2015) dan menurut Kemkominfo jumlah pengguna internet di Indonesia mencapai 82 juta orang dan berada pada peringkat ke-8 dunia. Dari jumlah tersebut, 80 persen diantaranya adalah remaja berusia 15-19 tahun" (Astuti et al., 2016). Terlebih lagi di era pandemi Covid 19 dimana pembelajaran dilakukan secara daring atau jarak jauh.

Menurut 4 menteri indonesia, satuan pendidikan harus memperhatikan zona wilayahnya dalam menentukan aktivitas pembelajaran. Untuk Level 1 dan 2 dapat memulai pembelajaran tatap muka (PTM) Terbatas, dengan mengutamakan kehati-hatian, keselamatan, dan kesehatan warga sekolah. Sementara untuk daerah yang berada di Level 3 dan 4, masih harus menggelar pembelajaran secara jarak jauh (PJJ) (Kemendikbud, 2019).

Berdasarkan himbauan di atas dapat disimpulkan bahwa penggunaan internet masih dibutuhkan dalam proses belajar mengajar meskipun wilayah tersebut masuk dalam kategori level 1 dan 2. Kementerian Kesehatan, Senin (18/10), yang menyebutkan Kota Mataram masuk level satu PPKM, bersama lima kabupaten/kota lainnya di NTB, ia mengatakan keberhasilan Mataram bisa hijrah dari level dua ke PPKM level satu merupakan hasil ikhtiar dan kedisiplinan masyarakat dalam menerapkan protokol kesehatan (Wahyono, 2021).

Adapun yang dimaksud dengan pemanfaatan internet secara sehat, cerdas, kreatif dan produktif adalah cerdas dalam memanfaatkan teknologi internet yaitu mencari suatu informasi yang sesuai dengan kebutuhan, baik kebutuhan dalam mencari suatu pelajaran, daring atau hal-hal penting lainnya. Hal-hal yang sudah didapatkan di internet dapat dikembangkan dan diterapkan di dalam kehidupan sehari-hari. Teknologi internet merupakan ladang ilmu untuk menambah pengetahuan (Obeit, 2019).

Adapun tujuan dari penelitian ini adalah untuk mengetahui bagaimana pemanfaatan https://journal.universitasbumigora.ac.id/index.php/ADMA 
internet tersebut, apakah teknologi internet tersebut dimanfaatkan dengan baik, dan teknologi internet dapat digunakan dengan baik sesuai dengan kebutuhannya. Sehingga diperlukan sosialisasi Internet Sehat, Cerdas, Kreatif dan Produktif di Era Pandemi Covid 19.

\section{Metode}

Penelitian ini merupakan penelitian kualitatif. Hunowu (2019) menyebutkan bahwa penelitian kualitatif adalah penelitian yang bermaksud untuk memahami fenomena tentang apa yang dialami oleh subjek penelitian misalnya perilaku, persepsi, motivasi, tindakan, dan lain-lain, secara holistic, dan dengan cara deskripsi dalam bentuk kata-kata dan bahasa, pada suatu konteks khusus alamiah dan dengan memanfaatkan berbagai metode alamiah. Dalam penelitian ini, peneliti akan memaparkan fakta apa yang ditemukan dilapangan dan dijabarkan secara rinci. Selanjutnya, data-data yang sudah dikumpulkan akan diolah dan dianalisis. Hal tersebut mampu menghasilkan hasil penelitian berupa penjabaran yang mendalam mengenai ucapan, tulisan, atau perilaku yang bisa diamati dalam suatu lingkup tertentu yang dilihat dari sudut pandang yang komprehensif (Moleong, 2014).

\section{Teknik Pengumpulan Data}

Teknik pengumpulan data yang digunakan peneliti dalam mengumpulkan data yaitu teknik observasi, wawancara, dan dokumentasi.

\section{Obsevasi}

Adapun pada penelitian ini peneliti secara langsung melakukan survey lokasi penelitian untuk mendapatkan data yang valid, atau sesuai dengan keadaan yang ada dilapangan dan lokasi bertempat di MA NW Tanak Maik Masbagek (PONPES ASH SHANDI NW).

\section{Wawancara}

Dalam teknik wawancara ini, peneliti menggunakan wawancara terstruktur. Adapun yang dimaksud wawancara terstruktur adalah peneliti sudah mengatur sedemikian rupa pertanyaan yang akan diajukan ke responden secara berurutan mengenai "Internet Sehat, Cerdas, Kreatif dan Produktif di Era Pandemi Covid 19" di MA NW Tanak Maik Masbagek (PONPES ASH SHANDI NW).

a. Instrument Penelitian

Instrumen penelitian sesuai dengan tujuan penetian yaitu: 1) bagaimanakah internet sehat, cerdas, kreatif dan produktif di era pandemi covid 19, 2) apakah internet sehat, cerdas, kreatif dan produktif di era pandemi covid 19 dapat diterapkan?

b. Solusi Peneliti

Adapun tugas peneliti adalah memberikan solusi setelah mengetahui permasalahan 
yang ada di MA NW Tanak Maik Masbagek (PONPES ASH SHANDI NW) ditemukan. Solusi yang diberikan berkaitan dengan bagaimana penggunaan internet sehat, cerdas, kreatif dan Produktif bisa diterapkan dalam kehidupan sehari-hari, agar berdampak baik atau positif.

\section{Dokumentasi}

Adapun yang akan didokumentasikan oleh peneliti yaitu berupa foto saat sedang berlangsung dilaksanakannya penelitian tersebut yang bertempat di MA NW Tanak Maik Masbagek (PONPES ASH SHANDI NW)

\section{Subjek dan Ojek}

Subjek dan objek merupakan sasaran dalam penelitian untuk mendapatkan tujuan tertentu mengenai permasalahan yang akan dibuktikan secara objektif. Subjek penelitian merupakan suatu atribut atau sifat atau nilai dari orang, objek atau kegiatan yang mempunyai variabel tertentu yang ditetapkan untuk dipelajari dan ditarik kesimpuan.

Berdasarkan definisi di atas maka dapat ditarik kesimpulan bahwa subjek penelitian menjadi sangat penting dalam penelitian, karena berhubungan dengan judul penelitian dan data yang diperlukan. Objek penelitian juga penting karena objek penelitian digunakan untuk mendapatkan data yang sesuai dengan tujuan artinya penentuan objek penelitian harus mendukung judul dan data penelitian karena dapat mempengengaruhi hasil penelitian tersebut.

Subjek dalam penelitian ini adalah guru, orang tua wali dan siswa, guru dan siswa merupakan pelaku dalam hal ini, yang dimaksud adalah sebagai pengguna teknolgi internet, sedangkan objek dari penelitian ini adalah teknologi internet.

\section{Pembahasan}

Penelitian ini membahas tentang "Internet Sehat, Cerdas, Kreatif dan Produktif di Era Pandemi Covid 19. Adapun maksud dari internet sehat dan cerdas adalah bagaimana cara menggunakan dan memanfaatkan internet ke arah yang lebih positif dan tidak ke arah yang sifatnya negatif seperti memanfaatkan internet dalam memperkaya wawasan dalam memahami pelajaran atau permasalahan yang ada di lingkungan sekitar. Sedangkan kreatif yaitu peserta dapat memberikan sesuatu yang baru, ide baru atau dapat mengembangkan apa yang sudah didapatkan dari internet sehingga dapat memberikan hasil yang memuaskan, dan produktif adalah peserta dapat mengetahui bagaimana cara menggunakan dan memanfaatkan teknolgi internet dengan menyalurkan ide-ide baru yang sudah dikemabangkan atau produk-produk dari hasil menonton video kerajinan tangan dan sejenisnya sehingga peserta dapat penghasilan tambahan.

Penggunaan dan pemanfaatan teknologi internet secara sehat, cerdas, kreatif dan produktif, berdasarkan tujuannya, antara lain: 
1. Dapat mencari materinya dengan menggunakan teknologi internet tersebut supaya dapat menambah wawasan dan ilmu pengetahuan. Teknologi tersebut juga dapat digunakan dalam melaksanakan pembelajaran secara online atau biasa disebut dengan Daring di masa pendemi covid 19.

2. Menerapkan dan mengembangkan apa yang sudah didapatkan di internet dalam kehidupan sehari-hari.

\section{Gambar pelaksanaan kegiatan:}

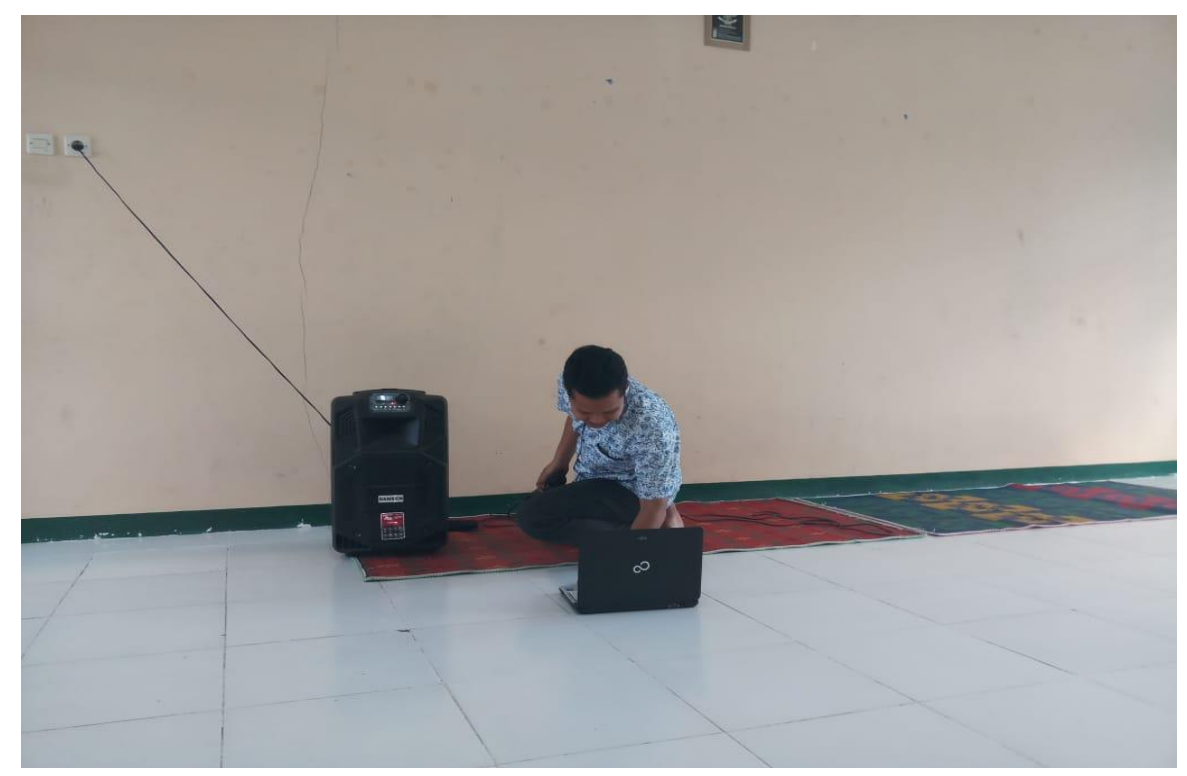

Gambar 1. Foto persiapan pengabdian masyarakat

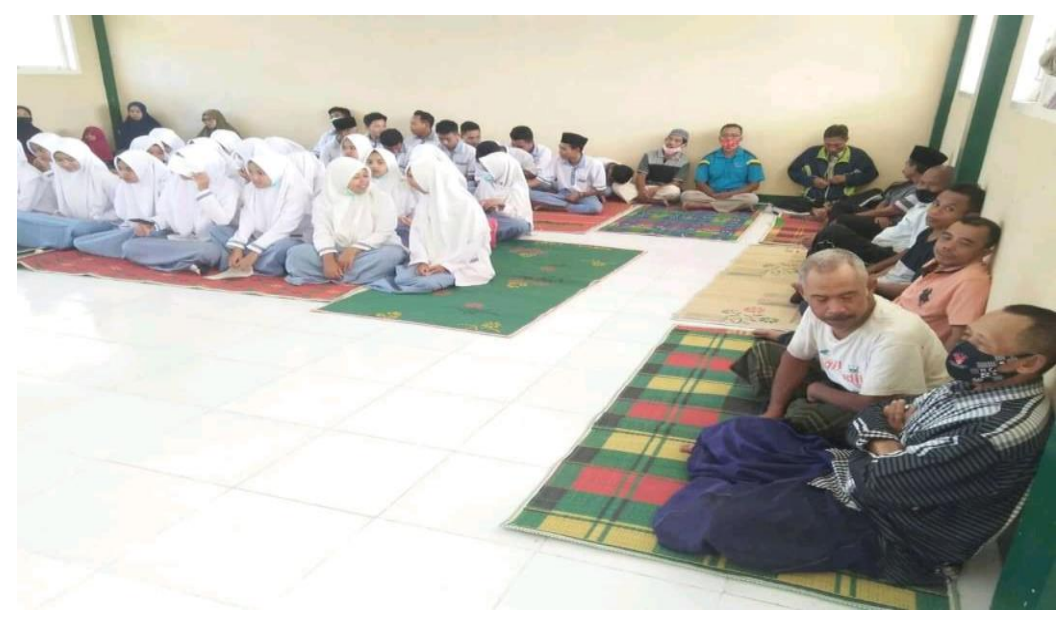

Gambar 2. Foto peserta pengabdian masyarakat 


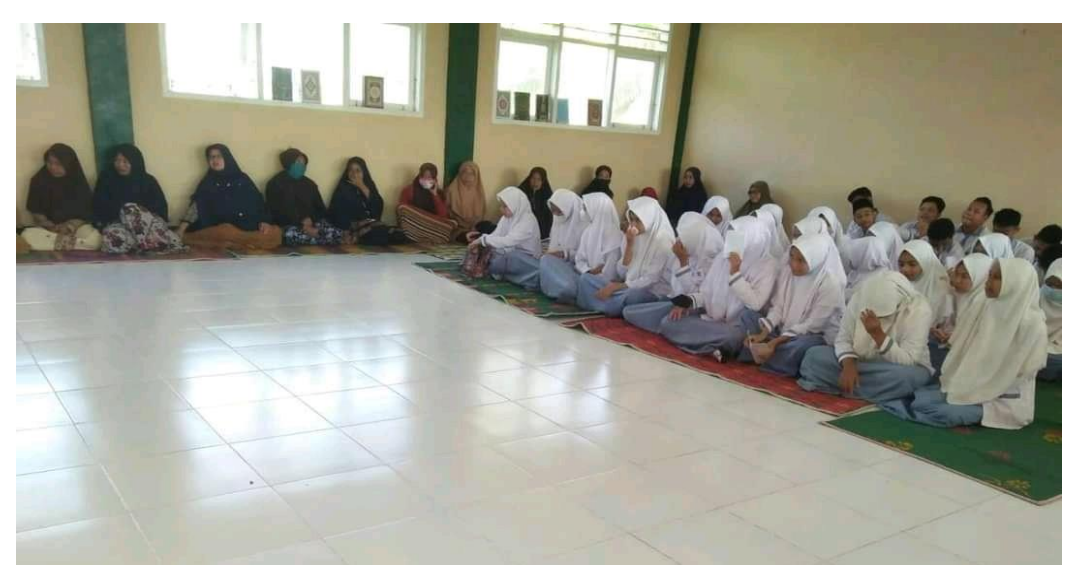

Gambar 3. Foto peserta pengabdian masyarakat

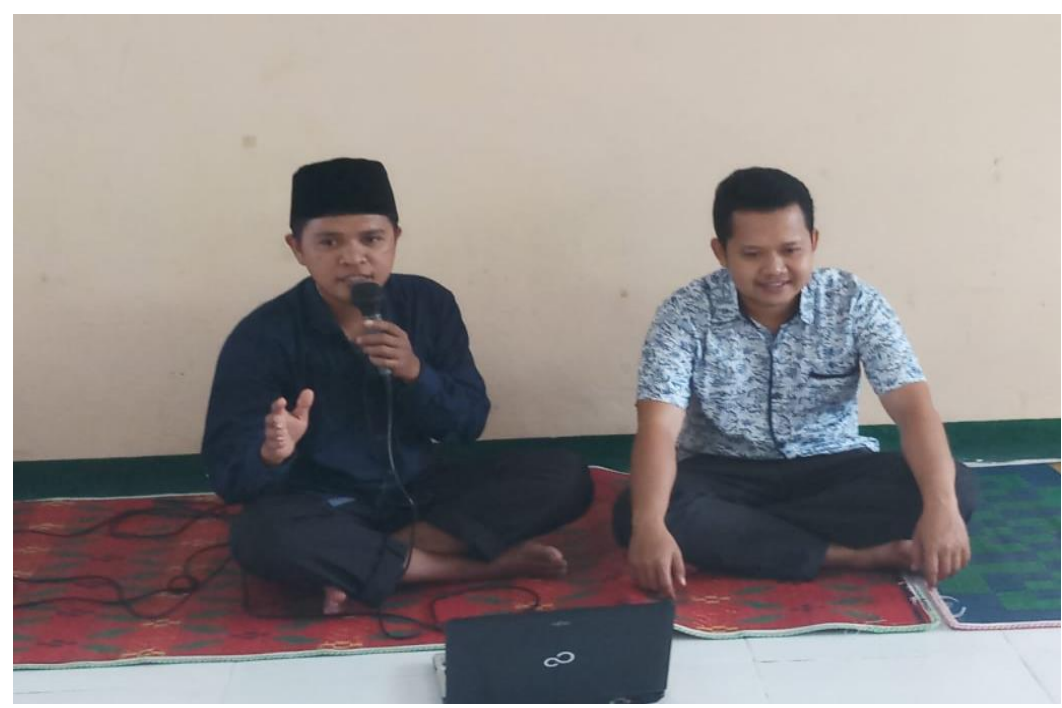

Gambar 4. Foto pemateri-pemateri pengabdian masyarakat

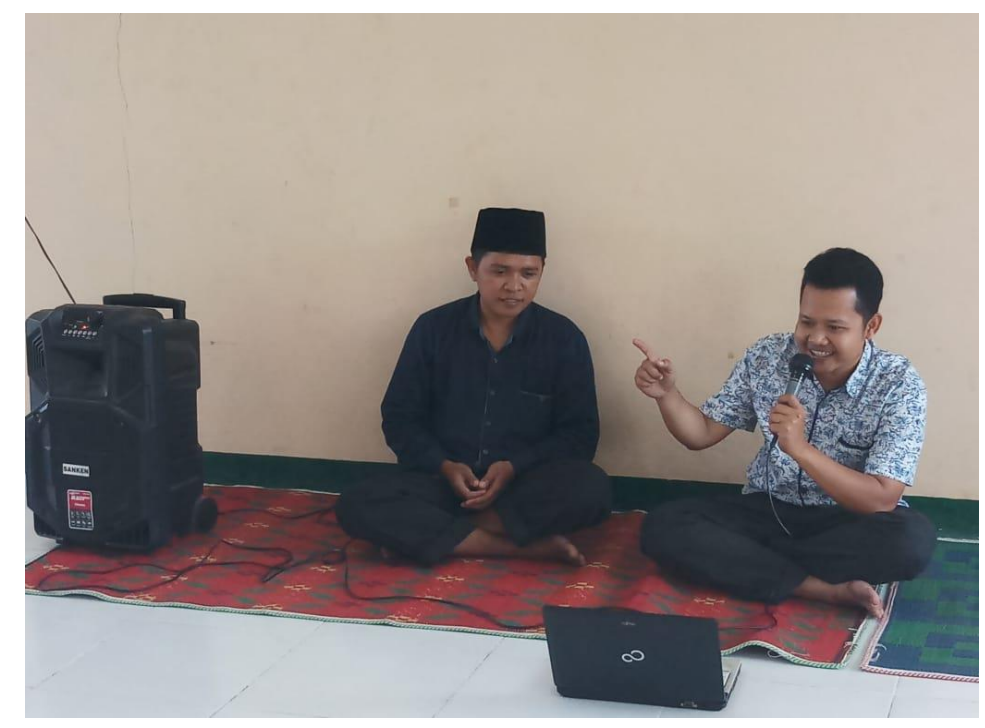

Gambar 5. Foto pemateri pengabdian masyarakat

Berdasarkan Gambar 1 dapat dilihat peneliti sekaligus pemateri sedang 
mempersiapkan bahan presentasi sosialisasi. Bahan yang digunakan dalam sosialisasi ini sangat standar yaitu laptop dan sound sistem sebagai pengeras suara. Gambar 2 dan gambar 3 foto para peserta yang sedang memperhatikan pemateri sosialisasi dalam menyampaikan materi tentang internet secara sehat, cerdas, kreatif dan produktif. Gambar 4 dan gambar 5 pemateri menjelaskan bagaimana menggunakan dan memanfaatkan teknologi internet dengan baik.

Dalam sosialisasi internet secara sehat, cerdas, kreatif dan produktif peneliti dan tim hanya menggunakan pasilitas yang seadanya dimana hanya bermodal laptop dan sound sistem sebagai pengeras suara karena keterbatasan alat, akan tetapi meskipun demikian alhamdulillah acara sosialisasi berjalan dengan lancar dan antusias peserta yang ikut serta dalam sosialisasi internet secara sehat, cerdas, kreatif dan produktif sangat terlihat jelas saat acara berlangsung dimana kami menerima beberapa pertanyaan dan masukan dari para peserta.

Berdasarkan pembahasan yang sudah dipaparkan di atas, hasil dari penelitian ini menemukan ada dua permasalahan, antara lain:

1. Peserta belum terlalu memahami bagaimana penggunaan dan pemanfaatan teknologi internet dengan baik. Peneliti sekaligus pemateri memaparkan bagaimana penggunaan dan pemanfaatan teknologi internet tersebut dan apa yang sebenarnya yang dimaksud dengan internet sehat, cerdas, kreatif dan produktif.

2. Kurangnya evaluasi dan kontrol guru pada peserta didik. Evaluasi dan kontrol; akan dilaksanakan dan dipantau oleh guru maksimal 1 kali dalam sebulan dan minimal akan dilakukan satu kali dalam satu semester. Evaluasi dapat dilihat dari bagaimana perubahan tingkah laku siswa, respon siswa dalam pembelajaran dan tugas yang diembankan guru kepada siswa.

\section{Kesimpulan}

Berdasarkan permasalahan yang sudah dipaparkan di atas dan sesuai dengan tujuan penelitian. Dapat disimpulkan bahwa, penggunaan dan pemanfaatan teknologi dengan baik, lebih mengarah kedampak positif dan mengurangi dampak negatif. Dengan mengetahui bagaimana cara penggunaan teknologi internet dengan baik dan benar, maka akan dapat membuat peserta didik menjadi, cerdas, kreatif dan produktif. Maksud dari cerdas, kreatif dan produktif yaitu peserta didik dapat mengembangkan dan menerapkan apa yang sudah didapatkan dalam tekologi internet tersebut diterapkan dalam kehidupan sehari-harinya, baik dilingkungan sekolah ataupun di luar lingkungan sekolah. 


\section{UcapanTerimakasih}

Puji dan syukur peneliti panjatkan kepada Alloh SWT, atas ridho-Nya sehingga penyusunan jurnal pengabdian kepada masyarakat ini dapat berjalan lancar, serta terima kasih kepada pihak-pihak yang terlibat dalam penyusunan jurnal pengabdian kepada masyarakat ini.

1. Terima kasih kepada guru dan siswa yang sudah mendukung dalam menyelesaikan penelitian atau sosialisasi ini, dan sudah meluangkan waktu untuk diwawancara.

2. Terima kasih kepada orang tua wali murid, yang sudah mendukung dan menghadiri acaranya, sehingga penelitian ini berjalan lancar.

\section{Daftar Pustaka}

Astuti, S. D., Putri, I. P., \& Ali, D. S. F. (2016). Strategi Komunikasi Program Internet Sehat Dan Aman Kementerian Komunikasi Dan Informatika Republik Indonesia (Studi Kasus Evaluasi Program Incakap Tahun 2015. Jurnal Komunikasi, 8(1), 25-35.

Hakim, S. N., Raj, A. A., \& Prastiwi, D. F. C. (2016). Remaja dan internet. Prosiding SEMNAS Penguatan Individu Di Era Revolusi Informasi, 2008, 311-319.

Hunowu, R. P. S. (2019). Kajian Bentuk Visual Dan Analisis Ornamen Pada Masjid Hunto Sultan Amay Gorontalo. http://elibrary.unikom.ac.id/id/eprint/1281/9/UNIKOM_RISTI P.S HUNOWU_BAB 3.pdf

Kemendikbud. (2019). Pelaksanaan Pembelajaran Tahun Ajaran Baru 2021/2022 Mengacu pada Kebijakan PPKM dan https://www.kemdikbud.go.id/main/blog/2021/08/pelaksanaan-pembelajaran-tahun-ajaran-baru20212022-mengacu-pada-kebijakan-ppkm-dan-skb-4-menteri

Maryono, Y., \& Istiana, B. P. (2019). Teknologi Informasi dan Komunikasi Edisi 3. Quadra.

Moleong, M. (2014). Metodologi Penelitian. http://repository.stiedewantara.ac.id/1164/5/BAB III.pdf

Obeit, E. (2019). Dampak Positif dan Negatif Internet. https://qwords.com/blog/dampak-positif-dannegatif-internet/

Simargolang, M. Y., Widarma, A., \& Irawan, M. D. (2021). Jaringan Komputer. Yayasan Kita Menulis.

Wahyono, E. (2021). Mataram Lombok PPKM Level 1, CFD Dibuka Lagi Awal Bulan. https://news.detik.com/berita/d-5772374/mataram-lombok-ppkm-level-1-cfd-dibuka-lagi-awalbulan 